Yu.S. Rud, orcid.org/0000-0001-8611-1219, V. Yu. Bilonozhko, orcid.org/0000-0003-2933-3549
Kryvyi Rih National University, Kryvyi Rih, Ukraine, e-mail: rudusprof@gmail.com

\title{
NEW ASPECTS OF THE METHODOLOGY FOR ASSESSING THE COMPLEXITY OF THE STRUCTURE OF TECHNOLOGICAL SYSTEMS OF THE MINING AND METALLURGICAL COMPLEX
}

Purpose. To develop a new approach to evaluating the complexity of the structure of technological systems of mining and metallurgical complex with the proposed integrated index. The practical application of this indicator is due to the methodological difficulties arising when determining the hierarchical level of the elements of the systems studied.

Methodology. A systematic approach is applied that allow us to explore industrial complexes of equipment as systems objects and present them in the form of technological systems. Methods of analysis and synthesis are used that allow us to identify common elements in the known methods for estimating the complexity of systems and to develop a new methodological approach to the process of decomposition systems. Methods of simulation of technological systems are applied, which allow submitting them in the form of models - structural-element schemes.

Findings. A new methodological approach is proposed to quantify the complexity of the structure of technological systems of mining and metallurgical complex, in which the process of decomposition of the system is performed by the method of successive cut-off of element connections with the system. Using the proposed decomposition method provides high accuracy and reliability when comparing technological systems with the structure of different hierarchical levels and consisting of a different number of subsystems and elements. Approbation of the developed method on the example of the pelletising plant pellets No. 2 of Pivnichnyi Mining and Processing Plant (Kryvyi Rih). It is shown that in the real technological systems the complexity of the structure occurs mainly due to the series connection of extra equipment rather than creating new relations. To increase the index of relative complexity of the technological system management structure, it is reasonable to use a combined series-parallel connection of additional technological equipment, which ensures the highest hierarchical level of the elements in the system.

Originality. The originality of the new approach to assessing the complexity of structure of the technological systems of mining and metallurgical complex is to develop a method of decomposition of the system, the essence of which consists in the successive cutting off of the connection of the elements with the system.

Practical value. The practical value of methodological approach the developed by the authors to estimate the complexity of the structure of the technological systems of the mining and metallurgical complex is that in contrast to the known method, the quantitative evaluation of system structure complexity is performed without performing the operation of the formal description of the structure. It provides high accuracy and reliability of the result, reduces the complexity of the evaluation process.

Keywords: technological system, the hierarchical level, decomposition of the system, the pelletizing plant pellets

Introduction. Industrial enterprises of the mining and metallurgical complex for the extraction and processing of iron ore raw materials are complex technological systems. These systems are a collection of production equipment and service personnel that interact in a common material, energy and information flow. Raw materials, energy and information enter the technological system. The output of the system involves finished products (materials), production waste and information (other). The technological systems of the mining and metallurgical complex are distinguished by the use of unique production equipment with high productivity, a complex structure of construction and interaction, and a high hierarchical level. An important problem arising when designing technological systems of the mining and metallurgical complex is to obtain a reliable quantitative assessment of the complexity of their structure. Technological systems that have different structural complexity and are equipped with different nomenclature of equipment, while performing the specified production functions, will have significant differences in technical, operational, economic and other important parameters. When choosing the best technological system, the less complex is usually chosen from two identical systems, therefore, the complexity must be quantified. The authors of [1] emphasize that complexity continues to be a problem in production systems. Complexity assessment realizes the ability to reduce and manage the sources of complexity, which helps to reduce the associated engineering costs and time, and increases the productivity and profitability of systems. In [2], it is noted that the main reason for studying the complexity of production systems

(C) Rud Yu. S., Bilonozhko V.Yu., 2021 is that the behavior of such systems should be understandable and predictable. This will enable the development of more efficient and predictable production systems. The authors of the article [3] note that the complexity assessment is necessary so that it can be effectively controlled, but now there are no practical tools for this. One of the reasons for an unsuccessful engineering solution may be a lack of understanding of the consequences of changes in projects due to their complexity. The work [4] presents a method for determining the degree of influence on the cost of production and project delay of various levels of complexity, as well as assessing alternative options for changes. A prerequisite for understanding the behavior of production systems is the presence of quantitative indicators of complexity. A quantitative assessment of the complexity of the structure of different systems, when they perform the specified functions, is associated with a number of technical, operational, economic and other important qualities. Unlike modern production systems, the MFF system architecture presented in [5] allows one to more accurately estimate the required level of complexity and better adapt the effective ontological complexity to this level. The authors of [6] note that despite efforts to manage complexity in product development, manufacturing around the world is facing high and growing complexity. Measuring the complexity of a production is critical to its management, so a practical measurement tool is provided that captures the complexity factors and the resulting effects of complexity. The complexity of the structure determines the capital costs for the construction of technological systems and the current costs of their operation. The second important task to be solved when designing technological systems of the mining and metallurgical complex is the selection of the range of tech- 
nological equipment for filling the structure of the system. The range of equipment should ensure the full implementation of the technological process for processing iron ore raw materials, the reliability and continuity of this process, and obtaining of the maximum economic effect at the lowest cost.

Literature review. Technological systems of the mining and metallurgical complex belong to the class of complex systems, since they have the following properties: a large number of elements (technological equipment) that make up the system; system elements are represented by a wide range of technological equipment with different properties; variety of possible forms of connections between elements and subsystems; complex functioning of the system, which is expressed in the implementation of technological processes that are difficult to describe mathematically; high level of hierarchical structure of the system. A quantitative assessment of the complexity of the structure of technical systems is one of the most difficult problems of systems engineering, which is the subject of a number of scientific works of domestic and foreign scientists. In [7], it is noted that in recent years a number of methods have been proposed for analyzing the complexity of production, developed on the basis of different theories and approaches. The definition of the concept of complexity is given and a number of ideas about the types of complexity are given. The complexity of systems can be physical and functional. In turn, physical complexity is further classified into two types, namely static and dynamic ones. Static complexity, also called structural complexity, is related to the structure and configuration of the system, the types of components in the system. Dynamic complexity refers to the uncertainty in the behavior of a system over a period of time and deals with the probability that the system will be under control. Dynamic complexity is associated with reliability. In [8], a method based on the use of information entropy is used to measure the complexity of a production system configuration. The article [7] proposes metrics of sensitivity and complexity based on one-time values and system relationships. The relationship between performance and complexity provides the ability to create an optimized system configuration with targeted properties. It is fairly argued that the level of complexity of existing systems is different from the optimal one. It is proposed to use sensitivity analysis to determine the coefficient of relevance of various types of connections, which will contribute to a more accurate measurement of the complexity of the system. In [9], it is argued that one of the problems of systems analysis is the estimation of their complexity. The complexity of the system is a qualitative characteristic for which there are still no formal assessment methods. The complexity of systems should depend on its structure, but the number of elements and connections does not directly affect the complexity of the system. The need to assess the complexity of systems is due to the need to determine the operational, technological, technical, and economical and design characteristics of the created or existing systems. The authors of [10] note that with an increase in the complexity of production systems, traditional design methods do not contribute to the implementation of high requirements for their reliability. They revised complexity theory and the relationship between complexity and reliability. In [11], it is noted that in the models previously presented to optimize the reliability of sequential and parallel systems, there is a limiting assumption that all components of a subsystem must be homogeneous. This limits the choice of components for industrial system designers and prevents higher levels of reliability from being achieved. A new model for optimizing the reliability of sequential and parallel systems is proposed, which allows the use of heterogeneous components in each subsystem. In [12], it is believed that the main reasons for the constantly growing complexity of production systems are a variety of factors, including technological advances, the uncertainty of the global market and mass personalization. The authors of [13] believe that a reliable production system is required for the flawless manufacture of designed products. An effective way to improve the reliability of production systems is to reduce their complexity. Reliability-based complexity analysis studies for a manufacturing system are rare. An axiomatic model for analyzing the complexity of a production system based on a fuzzy axiomatic domain mapping is proposed. In [14], a method is proposed for a comprehensive assessment of the complexity of the structure of technological systems of mining and processing plants. The method includes the analysis of the production system using the criteria for the occurrence of failures of elements (technological equipment) and the restoration of their performance; construction of a structural element diagram of a technological system; formal description of the technological system; assessment of the hierarchical level of elements and subsystems; quantitative assessment of the complexity of the structure of technological subsystems and the system as a whole. The method has been brought to a level suitable for practical use, has been tested in assessing the complexity of the structure of technological systems of mining and processing plants. However, the practical application of the criterion is associated with certain methodological difficulties in assessing the hierarchical level of the elements of the systems under study. Thus, a large number of works are devoted to the problem of assessing the complexity of the structure of systems for various purposes (for example, in article [1], reference is made to 93 scientific works.

Purpose. Development of a new method for assessing the complexity of the structure of technological systems of the mining and metallurgical complex, which is distinguished by a methodological approach to determining the hierarchical level of the studied elements and subsystems.

Methods. When performing the work, a systematic approach was applied, which made it possible to study industrial complexes of equipment as system objects and represent them in the form of technological systems. The methods of analysis were used, which made it possible to identify the most important common elements in the known methods for assessing the complexity of systems, as well as synthesis methods, on the basis of which a new methodological approach to assessing the complexity of the structure of technological systems was developed. Methods for modeling real technological systems were applied, which made it possible to represent them in the form of models - structural element diagrams. Experimental methods, the role of which is emphasized in [15], are relevant for the studies performed.

Peculiarities of the methodology for assessing the complexity of the structure. The proposed method for quantitative assessment of the complexity of the structure $S_{0}(n)$ of technological systems $C_{0}(n)$ is based on the following initial assumptions [14]: 1). Each $i^{\text {th }}$ element of the technological system $C_{0}(n)$ has one "input $A$ " and one "output $B$ ". "Input $A$ " of the $i^{\text {th }}$ element is understood as a channel through which the previous $(i-1)^{t h}$ element of the system or the external environment affects this element, changing its state. "Output $B$ " of the ith element is understood to be the channel through which this element acts on the next $(i+1)^{t h}$ element or the external environment by changing its state. 2). The state of "output $B$ " of the ith element is uniquely determined by the state of its "input $A$ ". 3). The complexity of the structure $S_{i}(n=1)$ of a unit element of the technological system $C_{0}(n=1)$ is equal to one, i. e. $\left.S_{i}(n=1)=1.4\right)$. The complexity of the structure $S_{0}(n)$ of the technological system $C_{0}(n)$, consisting of n elements, tends to infinity as $n \rightarrow \infty$, i. e. $\lim _{n \rightarrow \infty} S_{0}(n)=\infty$. 5). The complexity of the structure $S_{0}(n)$ of the technological system $C_{0}(n)$ is determined by the number of elements of the system $n$, the number of connections between them $n_{C . E}$ and the external environment $n_{C}$, as well as the hierarchical level $I_{0}(n)$ of the system.

In accordance with the provisions of paragraphs $1-5$, the quantitative value of the complexity index $S_{0}(n)$ of the technological system $C_{0}(n)$ of the hierarchical level $I_{0}(n)$ is determined by the following mathematical expression 


$$
S_{0}(n)=n I_{0}(n),
$$

where $n$ is the number of elements of the technological system.

For the $j^{\text {th }}$ subsystem of the hierarchical level $I_{j}(n)$, the quantitative value of the complexity indicator $\mathrm{Sj}(\mathrm{nj})$ is determined by the following mathematical expression

$$
S_{j}(n)=n_{j} I_{j}\left(n_{j}\right),
$$

where $n_{j}$ is the number of elements of the $j^{\text {th }}$ subsystem.

Since the technological system $C_{0}(n)$ is formed from $j$ separate subsystems $S_{j}(n)$ by aggregation, the system complexity indicator $S_{0}(n)$ has the additively property, i.e. for the system $C_{0}(n)$, the following equality holds

$$
\mathrm{S}_{0}(n)=\sum_{i=1}^{j} S_{i}(n)=\sum_{i=1}^{j} n_{i} I_{i}\left(n_{j}\right) .
$$

The practical implementation of the initial premises of the well-known method [14] for the quantitative assessment of the complexity index $S_{0}(n)$ of technological systems $C_{0}(n)$ is associated with serious methodological difficulties arising in determining the value of the hierarchical level $I_{j}\left(n_{j}\right)$ of the $j^{\text {th }}$ subsystems, as well as the system as a whole $I_{0}(n)$. To determine the hierarchical level $I_{j}\left(n_{j}\right)$ of the $j^{\text {th }}$ subsystems and the system $I_{0}(n)$, it is necessary to first perform the operation of a formal description of the technological system $C_{0}(n)$. The ambiguity and complexity of the known approach to determining the hierarchical level of all components of the system $C_{0}(n)$ can lead to errors in assessing the complexity of the structure $S_{0}(n)$ of a technological system.

This article presents a simple and logical way to assess the hierarchical level $I_{j}\left(n_{j}\right)$ of the $j^{\text {th }}$ subsystems, as well as the system as a whole $I_{0}\left(n_{0}\right)$, which differs in the way of decomposition of the system. The decomposition process is performed by sequentially cutting off the connections of elements with the system, which provides an accurate and reliable estimate of the complexity of the structure $S_{0}(n)$ of the technological system $C_{0}(n)$. To determine the general laws of the decomposition process when assessing the hierarchical level $I_{j}\left(n_{j}\right)$ of the $j^{\text {th }}$ subsystems with a different number of elements $n$ and the nature of their connection in different structures, we will consider several arbitrary systems $C_{0}(n)$, consisting of one, two, etc. elements $(n=1,2,3, \ldots)$.

System $C_{0}(n=1)$, consisting of one element $1-01$, has two communication channels with the external environment "input $A$ " and "output $B$ " (Fig. 1). The total number of links in such a system is equal to two $n_{C}=2$. In the process of decomposition of the system $C_{0}(n=1)$, two operations of cutting the connections of the element $1-01$ with the external environment "input $A$ " and "output $B$ " are performed; the number of operations to cut the connections of the element with the external environment $n_{C}=2$. In accordance with item 3 of the initial prerequisites, the complexity of the structure of a unit element $S_{0}(n=1)$ of the technological system $C_{0}(n=1)$ is equal to one, i. e. $S_{0}(n=1)=1$. According to the mathematical expression (1), $S_{0}(n=1)=1 \cdot I_{0}=1$, whence $I_{0}=1$ when the $n_{C}=2$. Then the quantitative estimate of the hierarchical level $I_{0}(n=1)$ of the system $C_{0}(n=1)$, consisting of one element, can be found by the following formula

$$
I_{0}(n=1)=1=n_{C . C}-1,
$$

where $n_{C . C}$ is the number of operations to cut ties of the element with other elements or the external environment.

Consider the technological system $C_{0}(n=2)$, consisting of two elements 1-01 and 1-02, connected in series (Fig. 2).

The first element of the 1-01 system has two communication channels: with the external environment "input $A$ " and with the 1-02 system's element, i. e. $n_{C}=2$. In the process of decomposition, two operations are performed to cut the named connections of the first element of $n_{C . C}=2$. After cutting off the connections of the element $1-01$, the second element of the system 1-02 retains the connection only with the

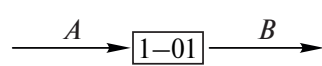

Fig. 1. The system $C_{0}(n)$, consisting of one element $1-01$

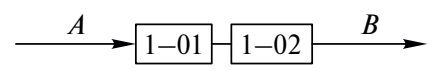

Fig. 2. System $C_{0}(n=2)$, consisting of two elements $1-01$ and 1-02 connected in series

external environment "output $B$ ": $n_{C}=1$. In the process of decomposition of element $1-02$, one operation of cutting the connection of element 1-02 with the external environment "output $B$ " is performed: $n_{C . C}=1$. Thus, in the process of decomposition of the system $C_{0}(n=2)$, consisting of two seriesconnected elements $1-01$ and $1-02$, it is necessary to carry out three operations of cutting the connections of the elements between them and with the external environment "input $A$ " and "exit $B$ ", i. e. the number of operations of cutting the links of the element of the system $n_{C . C}=3$. In accordance with formula (1), the quantitative estimate of the hierarchical level $I_{0}(n=2)$ of the system $C_{0}(n=2)$, consisting of two elements, will be

$$
I_{0}(n=2)=n_{C . C}-1=2 .
$$

Consider the technological system $C_{0}(n)$, consisting of $n$ elements $1-01,1-02, \ldots, n$, connected consequently (Fig. 3 ).

The first element of the 1-01 system has two communication channels: with the external environment "input $A$ " and with the $1-02$ system's element, i. e. $n_{C}=2$. In the process of decomposition, two operations of cutting the named connections of the first element are performed: $n_{C . C}=2$. After cutting off links of element $1-01$, element of system $1-02$ retains connection with the third element of system $1-03$, i. e. $n_{C}=1$. In the process of decomposition, one operation of cutting the connection of element $1-03$ with element $1-04$ is performed: $n_{C . C}=1$. The decomposition procedure must be repeated $n$ times for all subsequent elements $1-04,1-05, \ldots,(n-1)^{\text {th }}$, which have $n_{C}-1$ link between each other. After cutting off the connections of the $(n-1)^{\text {th }}$ element, the nth element of the system has a connection only with the external environment through the "output of element $B$ ". In the process of decomposition, the operation of cutting the connection of the $n^{\text {th }}$ element through "output $B$ " with the external environment is carried out, i.e. $n_{C . C}=1$.

Thus, in the process of decomposition of a technological system consisting of $n$ sequentially connected elements, it is necessary to carry out an $(n+1)-n$ operation of cutting the connections of elements between them and with the external environment through "input $A$ " and "output $B$ ": $n_{C . C}=n+1$. Taking into account item 3 of the initial prerequisites, according to which the complexity of the structure $S_{0}(n)$ of the unit element of the technological system $C_{0}(n=1)$ is equal to one, i. e. $S_{0}(n=1)=1$, and the mathematical expression (1), an estimate of the hierarchical level $I_{0}(n)$ of the system $C_{0}(n)$ with $n$ series-connected elements through the number of operations of cutting the links $n_{C . C}$ elements with the external environment or other elements of the system can be performed by the formula

$$
I_{0 . S E R .}(n)=n_{C . C}-1=n,
$$

where $n$ is the number of sequentially connected elements of the technological system.

Mathematical expressions (4, 5 and 6) are recurrent, so formula (6) is universal and can be used for any technological systems $C_{0}(n)$ consisting of $n$ elements connected in series.

Consider a technological system $C_{0}(n=2)$ consisting of two elements 1-01 and 2-01 connected in parallel (Fig. 4).

$$
\stackrel{A}{\longrightarrow}-1-01-1-02-\cdots-[1-n \stackrel{B}{\longrightarrow}
$$

Fig. 3. System $C_{0}(n)$, consisting of n elements connected in series 


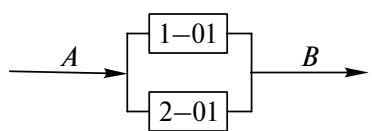

Fig. 4. A system $C_{0}(n=2)$ consisting of two elements 1-01 and 2-01 connected in parallel

System elements $1-01$ and $2-01$ have two communication channels between themselves and a common communication channel with the external environment - "input $A$ " and "output $B$ ", total $n_{C}=4$. In the process of decomposition, first two operations are performed to dissect the connections of the system with the external environment - "input $A$ " and "output $B$ ": $n_{C . C}=2$. After cutting off these connections, two connections between elements $1-01$ and 2-01 are preserved: $n_{C}=2$. In the process of further decomposition, two operations are performed to dissect the links between elements $1-01$ and 2-01: $n_{C . C}=2$. Thus, in the process of decomposition of the system $C_{0}(n=2)$, consisting of two parallel connected elements $1-01$ and $2-01$, four operations are performed to dissect the connections of elements between them and the external environment "input $A$ " and "output $B$ ", i. e. $n_{C . C}=4$. In accordance with the mathematical expression (6), the indicator of the hierarchical level $I_{0}(n)$ of the system $C_{0}(n=2)$, consisting of $\mathrm{n}$ parallel connected elements, is equal to

$$
I_{0}(n=2)=n_{C . C}-1=2 n-1=3 .
$$

Consider a system $C_{0}(n)$, consisting of $n$ elements $1-01$, $2-01, \ldots, n$ connected in parallel (Fig. 5).

The elements of the system $1-01$ and $2-01, \ldots, n$ have $2 n$ communication channels between themselves and common communication channels with the external environment "input $A$ " and "output $B$ ", i. e. the total communication channels of the $n_{C}=2 n+2$. In the process of decomposition, two surgeries are performed that cut ties with the external environment - "input $A$ " and "output $B$ ": $n_{C . C}=2$. After clipping those ties, there remain $2 n$ items $1-01,2-01, \ldots, n$. In the process of further decomposition, there are performed $2 n_{C . C}$ operations on dissection of relations between the elements $1-01$, $2-02, \ldots, n$, i.e. the total number of operations for dissecting the connections between the system elements and the external environment "input $A$ " and "output $B$ " is $n_{P A C . C B}=2 n_{C . C}-2+$ $+2=2 n$. Taking into account the above considerations, the formula (7), as well as the mathematical expression (6), we take the general formula for quantifying the hierarchical level $I_{0}(n)$ of the system $C_{0}(n)$, consisting of $n$ parallel connected elements, in the following form

$$
I_{0 . P A R .}(n)=n_{C . C}-1=2 n-1,
$$

where $n$ is the number of elements of the technological system connected in parallel.

Consider a technological system $C_{0}(n=4)$ of an arbitrary structure, which consists of four elements: 1-01, 2-01, 3-01 and 4-01 (Fig. 6).

Elements 2-01 and 3-01 are connected in parallel and form a separate subsystem, which is connected in series with elements $1-01$ and 4-01. System elements $1-01$ and 4-01 have communication channels with the external environment

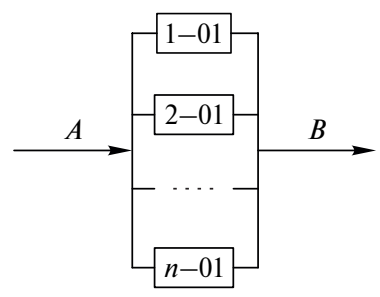

Fig. 5. A system $C_{0}(n)$ consisting of $n$ elements connected in parallel

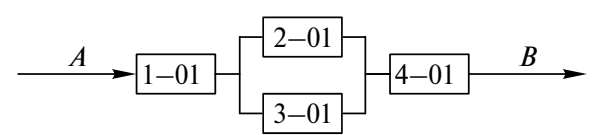

Fig. 6. Variant of the system structure $C_{0}(n=4)$ of four elements

"input $A$ " and "output $B$ ", as well as communication channels with the subsystem consisting of elements $2-01$ and $3-01$. In the process of decomposition of the system, two operations are performed for dissecting its connections with the external environment "input $A$ " and "output $B$ ": $n_{C . C}=2$. Then the channels of connections of elements 1-01 and 4-01 with the subsystem consisting of elements $2-01$ and $3-0$ are cut off. These are another two dissection operations $n_{C . C}=2$. After separating the subsystem consisting of elements $2-01$ and $3-01$, the links between elements $2-01$ and 3-01 are preserved.

In the process of decomposition, two operations are performed to dissect the links between elements $2-01,3-01: n_{C . C}=2$. Thus, in the process of decomposition of a system consisting of four elements $1-01,2-01,3-01$ and 4-01, two of which are connected in parallel, and two in series, six operations are performed to dissect the connections between the elements and the external environment "input $A$ " and "output $B$ ", i. e. $n_{C . C}=6$. In accordance with the mathematical expression (6), the hierarchical level of the system under consideration is $I_{0}(n=4)=5$. The technological system $C_{0}(n=4)$ is formed from three separate subsystems $C_{1}(1-01), C_{2}(2-01)$ and $C_{2}(3-01)$ and $C_{3}(4-01)$ by aggregation. The total value of the hierarchical level $I_{0}(n=4)$ of the technological system under consideration $C_{0}(n=4)$ of an arbitrary structure is expressed as the following sum (3)

$I_{0}(n=4)=I_{1}(n=1)+I_{2}(n=2)+I_{3}(n=1)=1+3+1=5$,

where $I_{1}(n=1), I_{2}(n=2), I_{3}(n=1)$ respectively, the hierarchical levels of subsystems of the technological system $C_{0}(n=4)$ and their quantitative estimates.

The result of equality (9) is equal to the value of the hierarchical level $I_{0}(n=4)$ of the technological system under consideration $C_{0}(n=4)$, which is obtained by the method for sequentially cutting off the connections of elements. In addition, the value of the hierarchical level $I_{0}(n=4)=5$ confirms the additively property possessed by the proposed complexity criterion.

Thus, the method for decomposition of systems by sequentially cutting off the connections of elements is applicable for technological subsystems and systems as a whole with a different number of elements having an arbitrary structure. The indicator of the hierarchical level $I_{0}(n)$ of the system has the property of additively and the total value of the hierarchical level $I_{0}(n)$ of the technological system $C_{0}(n)$ of an arbitrary structure can be determined as the sum of the hierarchical levels $I_{j}\left(n_{j}\right)$ of the corresponding subsystems $C_{j}\left(n_{j}\right)$ of the technological system $C_{0}(n)$.

Analysis of technological systems with different structures, which consist of an equal number of elements (for example, the structures of the systems shown in Figs. 2, 4; Figs. 3, 5), shows that the indicators of their hierarchical level $I_{0}(n)$ and the complexity indicators $S_{0}(n)$ differ in magnitude. Therefore, we can talk about a different degree of use of the potential of the structure of technological systems, consisting of $n$ elements, which is important in their creation. So far we are not talking about the most important property of systems - reliability. The relationship between structural complexity and reliability metrics will be discussed later. To quantitatively assess the degree of use of the potential of the structure of technological systems consisting of $n$ elements, it is proposed to use the relative indicator of the complexity of the structure $s_{0}(n)$, which is determined by the following mathematical expression

$$
S_{0}(n)=\frac{S_{0}(n)}{S_{0 \max }(n)}
$$

where $S_{0}(n)$ and $S_{0 \max }(n)$ are, respectively, the calculated (according to this method) and the maximum value of the com- 
plexity index of the structure of the technological system under consideration $C_{0}(n)$.

The value of the minimum $S_{0 \min }(n)$ and maximum $S_{0 \max }(n)$ indicators of the complexity of the structure of the considered technological systems $C_{0}(n)$ with an equal number of elements $n$, but different structure, is determined by their hierarchical level. Analysis of technological systems with serial connection of elements allows expressing the minimum value of the structure complexity index $S_{0 \min }(n)$ in the following mathematical expression

$$
S_{0 \min }(n)=n I_{0 \min }(n)=n I_{0 . S E R}(n)=n^{2} .
$$

Analysis of technological systems with parallel connection of elements allows expressing the maximum value of the structure complexity index $S_{0 \max }(n)$ by the following mathematical expression

$$
S_{0 \max }(n)=n I_{0 \max }(n)=n I_{0 . P A R}(n)=n(2 n-1) .
$$

The value of the minimum $S_{0 \min }(n)$ and maximum $S_{0 \max }(n)$ indicators of the complexity of the structure of systems $C_{0}(n)$ can be expressed in terms of the number of operations of cutting the $n_{C . C}$ element links with the external environment or with other elements of the system. The minimum value of the structure complexity index $S_{0 \min }(n)$ is described by the mathematical expression

$$
S_{0 \max }(n)=n I_{0 \min }(n)=n I_{0 . S E R}(n)=n\left(n_{C . C}-1\right)=n^{2},
$$

and the maximum value of the structure complexity index $S_{0 \max }(n)$ is the mathematical expression

$$
S_{0 \max }(n)=n I_{0 \max }(n)=n I_{0 \text { PAR }}(n)=n\left(n_{C . C}-1\right)=n(2 n-1) \text {. }
$$

The indicator of the relative complexity of the structure of the system $s_{0}(n)$ provides an opportunity to assess the degree of rationality of constructing technological systems consisting of n elements, excluding the influence on the result of the number of elements $n$ and ensuring the objectivity of the assessment

Fig. 7 shows the graphs of the dependences of the minimum $S_{0 \min }(n)$, maximum $S_{0 \max }(n)$ and the relative $s_{0}(n)$ indicators of the complexity of the structure of the system $C_{0}(n)$ on the number of elements of the system $n$.

According to the graphs, the values of the minimum $S_{0 \min }(n)$ and maximum $S_{0 \max }(n)$ indicators of the complexity of the structure of systems $C_{0}(n)$ grows with acceleration with an increase in the number of elements of the system $n$. The area between the curves $S_{0 \min }(n)$ and $S_{0 \max }(n)$ shows the range of possible variations of the system structure capabilities. The graph of the dependence of the relative indicator of the complexity of the structure $s_{0}(n)$ of technological systems $C_{0}(n)$ on the number of elements of the system $n$ features a hyperbolic character and is limited by the value limit $0.5-1.0$.

The nonlinear growth of indicators of the complexity of the structure $S_{0}(n)$ of the system $C_{0}(n)$ with an increase in the number of elements $n$ occurs due to the inclusion of addition-

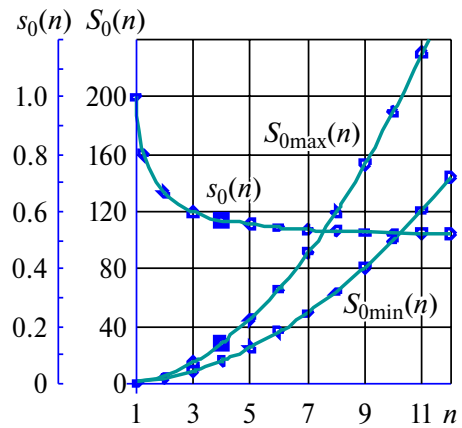

Fig. 7. Graphs of the dependences of the minimum $S_{0 \min }(n)$, maximum $S_{0 \max }(n)$ and relative $s_{0}(n)$ indicators of the complexity of the structure of systems $C_{0}(n)$ on the number of system elements $n$ al direct and reverse structural links in the work, an increase in the functionality of the system, and the stability of its functioning. At the same time, the range of permissible deviations of the parameters of the external environment, affecting the system $C_{0}(n)$, is expanding, redundant connections and elements are created, which leads to an increase in the reliability and efficiency of using technological systems. The existence of the developed method for quantitative assessment of the indicators of the complexity of the structure of the technological system $C_{0}(n)$ makes it possible, even in the process of its design and creation, to form variants of systems with structures of varying complexity when using the same number of elements, i. e. it is possible to purposefully control the quality of the created technological systems of the mining and metallurgical complex.

Fig. 8 shows a block diagram of the process equipment system of the pelletizing plant No. 2 of Pivnichnyi Ore Mining and Processing Plant (Kryvyi Rih). The technological scheme of the $C_{0}(n)$ system consists of separate subsystems $C_{j}(n)$. The elements of the structural diagram are technological equipment that implements the process of preparing raw materials for pelletizing and the process of pelletizing itself (L. K. Kokorin, S. N. Leleko, 2004). Let us estimate the hierarchical level $I_{0}(n)$ of the considered system $C_{0}(n)$ for six separate subsystems $C_{j}(n)$ of the technological equipment, using the obtained formulas ( 4 , $6,8)$. The calculation results are summarized in Table 1 .

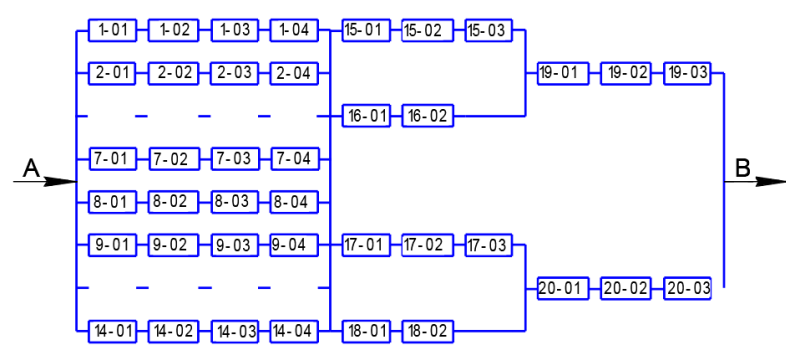

Fig. 8. Block diagram of the technological equipment system of the pelletizing plant for pellets No. 2 of Pivnichnyi Mining and Processing Plant (Kryvyi Rih)

Table 1

The results of the assessment of the hierarchical level $I_{j}\left(n_{j}\right)$ of

\begin{tabular}{|c|c|c|c|c|c|}
\hline 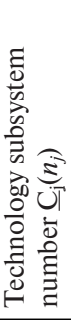 & Part numbers $n$ & 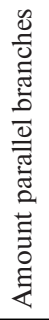 & 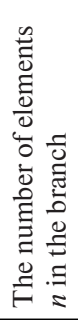 & 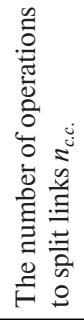 & 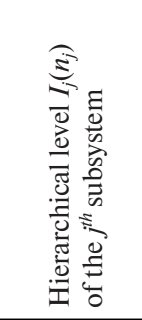 \\
\hline 1 & $\begin{array}{l}1-01 \ldots 1-04 ; 2-01 \ldots \\
2-04 ; \ldots 7-01 \ldots 7-04\end{array}$ & 7 & 4 & 35 & $I_{1}(35)=34$ \\
\hline 2 & $\begin{array}{l}8-01 \ldots 8-04 ; 9-01 \ldots \\
9-04 ; \ldots 14-01 \ldots 14-04\end{array}$ & 7 & 4 & 35 & $I_{2}(35)=34$ \\
\hline 3 & $\begin{array}{l}15-01,15-02,15-03 \\
16-01,16-02\end{array}$ & 2 & $3 / 2$ & 6 & $I_{3}(5)=5$ \\
\hline 4 & $\begin{array}{l}17-01,17-02,17-03 ; \\
18-01,18-02\end{array}$ & 2 & $3 / 2$ & 6 & $I_{4}(5)=5$ \\
\hline 5 & $19-01,19-002,19-03$ & 1 & 3 & 4 & $I_{5}(3)=3$ \\
\hline 6 & $\begin{array}{l}20-01,20-002, \\
20-03\end{array}$ & 1 & 3 & 4 & $I_{6}(3)=3$ \\
\hline- & "input $A$ " - "output $B$ " & 1 & 1 & 1 & $I_{6}(1)=1$ \\
\hline
\end{tabular}
the subsystems $C_{j}\left(n_{j}\right)$ of the system $C_{0}(n)$ of the technological equipment of the pelletizing plant for pellets No. 2

of Pivnichnyi Mining and Processing Plant (Kryvyi Rih) 
The values of the calculated indicators of the complexity of the structure of technological subsystems $S_{j}\left(n_{j}\right)$ of the technological equipment system of the pelletizing plant No. 2 of Pivnichnyi Ore Mining and Processing Plant (Kryvyi Rih)

\begin{tabular}{|l|l|l|l|}
\hline \multirow{2}{*}{$\begin{array}{c}\text { Subsystem } \\
\text { number } \\
C_{j}\left(n_{j}\right)\end{array}$} & \multicolumn{3}{|c|}{ Formulas for calculation and quantitative values of indicators of the complexity of the structure $S_{j}\left(n_{j}\right)$ of the $j^{t h}$ technological } \\
subsystems $C_{j}\left(n_{j}\right)$
\end{tabular}

The formulas and values of the calculated indicators of the complexity of the structure of technological subsystems $S_{j}\left(n_{j}\right)$ of the technological equipment system of the pelletizing plant No. 2 of Pivnichnyi Ore Mining and Processing Plant (Kryvyi Rih) are given in Table. 2.

The degree of use of the potential of the structure of the real system of technological equipment $C_{0}(n)$ of the pelletizing plant No. 2 of Pivnichnyi Mining and Processing Plant (Kryvyi Rih) is determined by the mathematical expression (10) and is

$$
S_{0}(n)=\frac{S_{0}(n)}{S_{0 \max }(n)}=\frac{990}{1601}=0.6184
$$

Conclusions. A new methodological approach to the quantitative assessment of the complexity of the structure of technological systems of the mining and metallurgical complex is proposed, in which the process of decomposition of the system is carried out by the method of sequentially cutting off the connections of elements with the system. The use of the proposed decomposition method provides a quantitative assessment of the complexity of the structure of technological systems with high accuracy and reliability, which is important for comparison of technological systems of the mining and metallurgical complex, which have a different structure, consisting of a different number of subsystems and elements with different hierarchical levels. Approbation of the developed decomposition method was carried out on the example of the system of technological equipment of the pelletizing plant No. 2 of Pivnichnyi Mining and Processing Plant (Kryvyi Rih). The degree of use of the potential of the structure under consideration is 0.6184 , which is a satisfactory indicator. To increase the indicator of the relative complexity of the structure of technological systems, it is rational to use a combined series-parallel connection of additional technological equipment, which provides a high hierarchical level of elements in the system.

\section{References.}

1. Alkan, B., Vera, D., Ahmad, M., Ahmad, B., \& Harrison, R. (2016 ). Project evaluation of automated production processes based on the complexity of control logic. Procedia CIRP, 50, 141-146.

2. Efthymiou, K., Mourtzis, D., Pagoropoulos, A., Papakostas, N., \& Chryssolouris, G. (2016). Manufacturing systems complexity analysis methods review. International Journal of Computer Integrated Manufacturing, 1025-1044. https://doi.org/ 10.1080/0951192X.2015.1130245.
3. Alkan, B., Vera, D.A., Ahmad, M., Ahmad, B., \& Harrison, R. (2018). Complexity in manufacturing systems and its measures: a literature review. European J. of Industrial Engineering (EJIE), 12(1), 116-150.

4. Herszon, L., \& Keraminiyage, K. (2014). Estimates of changes in technical systems and their impact on cost and duration, based on structural complexity. Procedia CIRP, 55(2016), 35-40. https://doi.org/10.1016/j.procir.2016.07.033. 5. Siegerta, J., Schlegela, T., Zarcoa, L., Miljanovica, B., Meykea, A., \& Bauernhansla, T. (2020). Ultra-flexible Factories: An Approach to Manage Complexity. Procedia CICIRP, 93, 329-334.

6. Brinzer, B., \& Schneider, C. (2020). Assessing complexity in production: linking complexity factors and effects. Procedia CIRP, 93, 694-699. https://doi.org/10.1016/j.procir.2020.04.014. 7. Gomes, V.M., Paiva, J.R. B., Marcio, R.C.R., Gabriel, A.W., \& Wesley. P.C. (2019). Mechanism for Measuring System Complexity Applying Sensitivity Analysis. Hindawi. https://doi.org/10.1155/2019/1303241.

8. Guoliang, F., Aiping, Li, Giovanni, M., Liyun, Xu, \& Xuemei, L. (2017). Measuring the complexity of an operationbased configuration for a production system. Procedia CIRP, 63, 645-650. https://doi.org/10.1016/j.procir.2017.03.136.

9. Sokolov, V. V. (n.d.). An approach to assessing the complexity of systems. Electronic journal. Assessment of the complexity of the system. Retrieved from http://www.ait.org.ua/p/pub_podhod.html.

10. Jiang Shao, Feigning Lu, Chenhui Zeng, \& Ming Xu (2016). Research Progress Analysis of Reliability Design Method Based on Axiomatic Design Theory. Procedia CIRP, 53, 107-112.

11. Feizabadi, M. (2017). A new model for reliability optimization of series-parallel systems with non-homogeneous components. Reliability Engineering \& System Safety, 157, 101-112. https://doi.org/10.1016/j.ress.2016.08.023.

12. Alkan, B., \& Harrison, R. (2019). Virtual engineering approach to checking the structural complexity of component automation systems at an early design stage. Journal of Production Systems, 53, 18-31. https://doi.org/10.1016/j.jmsy.2019.09.001. 13. Gu, C., He, Y., \& Han, X. (2016). Reliability-oriented Complexity Analysis of Manufacturing Systems Based on Fuzzy Axiomatic Domain Mapping. Procedia CIRP, 53, 130135. https://doi.org/10.1016/j.procir.2016.06.097.

14. Rud, Yu., \& Belonozhko, V. (2017). Development of the criterion and the method of estimation of the complexity of the structure of technological systems. Eastern-European jour- 
nal of enterprise technologies, 6/1(90), 4-11. https://doi. org/10.15587/1729-4061.2017.114433.

15. Samusya, V. I., Kirichenko, Yu. A., Cheberyachko, I. M., \& Trofimova, O.P. (2020). Development of experimental methods for the study of heterogeneous flows in the context of hydraulic lifting design. In: Actual scientific research of resource-saving technologies for the extraction and processing of minerals: collective monograph, (pp. 260-267). Sofia: Publishing House "St. Ivan Rylsky".

\section{Нові аспекти методології оцінки складності структури технологічних систем гірничо- металургійного комплексу}

\section{Ю. С. Рудь, В. Ю. Білоножкко}

Криворізький національний університет, м. Кривий Ріг, Україна, e-mail: rudusprof@gmail.com

Мета. Розробка нового підходу до оцінки складності структури технологічних систем гірничо-металургійного комплексу за допомогою запропонованого авторами комплексного показника. Практичне застосування цього показника пов'язане 3 методологічними труднощами, що виникають при визначенні ієрархічного рівня елементів досліджуваних систем.

Методика. Застосовано системний підхід, що дало змогу дослідити промислові комплекси обладнання як системні об'єкти та представити їх у вигляді технологічних систем. Використані методи аналізу й синтезу, що дозволило виділити у відомих способах оцінки складності систем загальні елементи й розробити новий методологічний підхід до процесу декомпозиції систем. Застосовані методи моделювання технологічних систем, що дозволило представити їх у вигляді моделей - структурно-елементних схем.

Результати. Запропоновано новий методологічний підхід до кількісної оцінки складності структури технологічних систем гірничо-металургійного комплексу, в якому процес декомпозиції системи виконується методом послідовного відсікання зв'язків елементів із системою. Використання запропонованого методу декомпозиції забезпечує високу точність і достовірність при порівнянні технологічних систем, що мають структуру різного ієрархічного рівня та складаються з різної кількості підсистем і елементів. Проведена апробація розробленого методу на прикладі фабрики огрудкування окатишів № 2 Північного гірничо-збагачувального комбінату (м. Кривий Ріг). Показано, що в реальних технологічних системах ускладнення структури відбувається, в основному, за рахунок послідовного включення додаткового обладнання, а не створення нових зв'язків. Для збільшення показника відносної складності структури технологічних систем раціональним $є$ використання комбінованого послідовно-паралельного включення додаткового технологічного обладнання, за якого забезпечується високий ієрархічний рівень елементів у системі.

Наукова новизна. Новизною підходу до оцінки складності структури технологічних систем гірничо-металургійного комплексу є розробка методу декомпозиції системи, суть якого полягає в послідовному відсіканні зв'язків елементів із системою.

Практична значимість. Практична значимість розробленого авторами методологічного підходу до оцінки складності структури технологічних систем гірничо-металургійного комплексу полягає в тому, що, на відміну від відомого методу, кількісна оцінка складності структури системи проводиться без виконання операції формального опису структури. Це забезпечує високу точність і достовірність результату, знижує трудомісткість процесу оцінки.
Ключові слова: технологічні системи, ієрархічний рiвень, декомпозиція систем, фабрики огрудкування окатишів

\section{Новые аспекты методологии оценки сложности структуры технологических систем горно-металлургического комплекса}

\section{Ю. С. Рудь, В. Ю. Белоножко}

Криворожский национальный университет, г. Кривой Рог, Украина, e-mail: rudusprof@gmail.com

Цель. Разработка нового подхода к оценке сложности структуры технологических систем горно-металлургического комплекса при помощи предложенного авторами комплексного показателя. Практическое применение этого показателя связано с методологическими сложностями, возникающими при определении иерархического уровня элементов исследуемых систем.

Методика. Применен системный подход, что позволило исследовать промышленные комплексы оборудования как системные объекты и представить их в виде технологических систем. Использованы методы анализа и синтеза, что позволило выделить в известных способах оценки сложности систем общие элементы и разработать новый методологический подход к процессу декомпозиции систем. Применены методы моделирования технологических систем, что позволило представить их в виде моделей - структурно-элементных схем.

Результаты. Предложен новый методологический подход к количественной оценке сложности структуры технологических систем горно-металлургического комплекса, в котором процесс декомпозиции системы выполняется методом последовательного отсечения связей элементов с системой. Использование предложенного метода декомпозиции обеспечивает высокую точность и достоверность при сравнении технологических систем, имеющих структуру разного иерархического уровня и состоящих из разного количества подсистем и элементов. Проведена апробация разработанного метода на примере фабрики окомкования окатышей № 2 Северного горно-обогатительного комбината (г. Кривой Рог). Показано, что в реальных технологических системах усложнение структуры происходит, в основном, за счет последовательного включения дополнительного оборудования, а не создания новых связей. Для увеличения показателя относительной сложности структуры технологических систем рациональным является использование комбинированного последовательнопараллельного включения дополнительного технологического оборудования, при котором обеспечивается высокий иерархический уровень элементов в системе.

Научная новизна. Новизной подхода к оценке сложности структуры технологических систем горно-металлургического комплекса является разработка метода декомпозиции системы, суть которого состоит в последовательном отсечении связей элементов с системой.

Практическая значимость. Практическая значимость разработанного авторами методологического подхода к оценке сложности структуры технологических систем горно-металлургического комплекса состоит в том, что, в отличие от известного метода, количественная оценка сложности структуры системы производится без выполнения операции формального описания структуры. Это обеспечивает высокую точность и достоверность результата, снижает трудоемкость процесса оценки.

Ключевые слова: технологические системы, иерархический уровень, декомпозиция систем, фабрики окомкования окатышей

Recommended for publication by N. V. Kijanovskij, Doctor of Technical Sciences. The manuscript was submitted 28.09.20. 